\title{
THE IMPACT OF MANAGEMENT ON GROUND VEGETATION IN RIGA'S URBAN FORESTS
}

\author{
Andis Kalniṇš, Inga Straupe, Līga Liepa \\ Latvia University of Agriculture \\ inga.straupe@1lu.1v
}

\begin{abstract}
Urban forests provide ecological and social functions and significantly improve esthetical value of these ecosystems. These forests also function as recreational areas for urban residents. The aim of this study was to assess the influence of understory cutting of different intensity on vegetation and coincidence with Myrtillosa forest type in Mežaparks, Riga. In total nine study sites were established: three sites adjacent to roads where regular undergrowth management is practiced, three adjacent sites to edges of the pathways, where undergrowth management is practiced only occasionally and three adjacent sites to roads where there is no management activity at all. Combined 54 sample plots were created (each sized $10 \times 10 \mathrm{~m}$, area $100 \mathrm{~m}^{2}$ ), where vegetation survey was done using Braun-Blanquet method. This study showed that with an increase in the intensity of undergrowth management, in general, the species richness and their coverage increases, or more specifically, the number of herbaceous and moss species increases, but the occurrence of shrub species decreases. In all study sites we observed the development of synantrophic species, especifically, the development of fructification which was indicated by the following species: Sambucus nigra L., Sambucus racemosa L., Amelanchier spicata Lam. If management intensity decreases, the proportion of competitor species decreases, but the proportion of CSR strategy type species stabilizes.
\end{abstract}

Key words: urban forests, vegetation, synantrophication, forest management.

\section{Introduction}

Urban forest ecosystems have evolved by interaction of human activities and natural processes. These ecosystems provide significant environmental (air purification and oxygen production, temperature and microclimate regulation, runoff reduction, soil protection, noise reduction, preservation of biodiversity) and social function (recreation, aesthetic values, cultural heritage sites, environmental education) (Emsis, 1980; Dwyer, McPherson, \& Schroeder, 1992; Tyrväinen et al., 2005; Bell, 2008; Chen \& Jim, 2008; Konijnendijk, 2008). Residents of urban forest prefer to use these forests for recreation closer to their place of residence (Konijnendijk \& Randrup, 2004). This demonstrates the importance of social role of urban forests, and the conservation of biodiversity in these forests is closely related to the recreational and landscape features (Alvey, 2006).

Various natural or anthropogenic disturbances affect the development of vegetation in forest ecosystems (Prieditis, 1999; Drobyshev, 2004). However, urban forests are also affected by direct human activities, such as trampling, campfires, and waste disposal, and indirect - promoting the dispersal of adventive and invasive species, changes in the amount of soil nutrients. In addition, urban forest ecosystems are characterized by synantrophication, which promotes the pollution and eutrophication of soils, as well as the increase of anthropogenic pressure (Laiviňš, 1998; Priedītis, 1999). High pressure from recreational activities causes the degradation of the understory vegetation, for instance, better lighting conditions increase the ruderal and grassland plant introduction. This causes the patch structure formation where disturbed and undisturbed areas in urban forest landscape appear (Эмсис, 1989; Trušiņš, 1990; Bell, 2008). Therefore, the succession processes in the urban forest ecosystems are strongly influenced by anthropogenic loads and appropriate sustainable forest management planning is essential to preserve these areas in longer term.

Understory vegetation is a significant landscapeforming element, which increasesthe diversity in vertical structure and openness while dense understory limits recreation opportunities and hinders forest regeneration. It is known that increaseddensity of shrub layer promotes fructification (Priedīitis, 1999). However, different studies have shown that for recreation activities people prefer to visit open forests or forested areas with low density in the undergrowth (Tyrväinen et al., 2005). Therefore it has to be taken into account and one of the most important management tasks is to provide the stability in terms of succession and improve the aesthetic values in these forests. The aim of this study was to assess different intensities undergrowth cutting effects on the understory plant diversity and conformation to Myrtillosa forest type in Mežaparks, Riga. The following study objectives were identified: 1) to characterize vegetation along the roads and trails in Mežaparks where understory cutting is done regularly, irregularly and left intact; 2) to compare and evaluate how different management intensity affects the understory vegetation.

\section{Materials and Methods}

The study was conducted in Mežaparks, located in Riga, the capital city of Latvia. Mežaparks is known since 1901 as a forest park. Its total area is 1182.1 


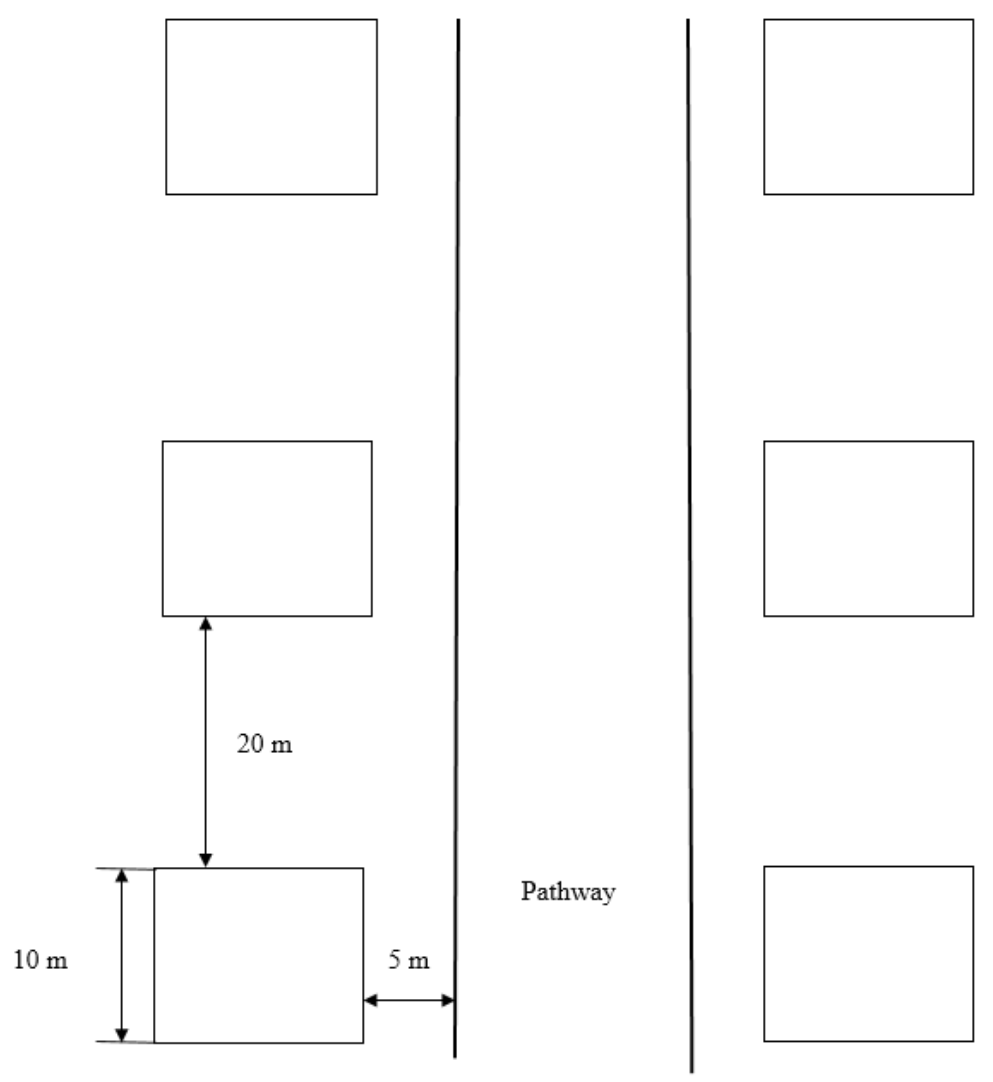

Figure 1. The schematic design of sample plot.

hectares large and it is dominated by Scots pine Pinus sylvestris L. forests with walking trails, recreational infrastructure, as well as residential houses on partly preserved sand dune terrain. The most important forest type is Myrtillosa, it occupies 55.9\% of the total area. Despite the long-term anthropogenic impact, few forest stands correspond to the European Union protected habitat type Western taiga forests (Jakovičs, 2013). The territory is maintained by the company Rīgas meži Ltd. and the infrastructure improvements for recreation purposes are regularly done (understory cutting once a year in $20 \mathrm{~m}$ wide strips on both sides along the roads and trails from 2004), irregularly done (in sites along the roads and trails where surface is not covered by asphalt and understory cutting is practiced occasionally - in 2012 and 2014) and intact sites (management activities have not been done). A study was carried out in the vegetation season of 2015. In total we selected nine study sites which correspond to the intensity of the management: three sites with regular understory cutting, three with irregular understory cutting and three intact sites. In each study site, in both sides along roads and trails, three sample plots were established with size $10 \mathrm{~m} \times 10 \mathrm{~m}$ and separating distance of $20 \mathrm{~m}$ (Fig. 1).

In each sample plot, the vegetation survey was done using Braun-Blanquet method. The total projective coverage of moss, herb (including vascular plants, dwarfshrubs, shrub and tree species up to the height of $0.5 \mathrm{~m}$ ), shrub (shrub and tree species at the height from 0.5 to $7.0 \mathrm{~m}$ ) and tree layers (tree species from the height of $7.0 \mathrm{~m}$ ) as well as coverage of each separate species was evaluated in each zone as percentage (\%). The occurrence for all plant species was calculated according to Raunkiaer constancy classes (I $<21 \%$ II $21-40 \%$, III $41-60 \%$, IV $61-80 \%$, V $81-$ $100 \%$ ) characterizing the plant species stability of objects (Markov, 1965; Muller-Dombois \& Ellenberg, 1974). All species in the herb layer were characterized by plant strategy groups (C-S-R) (Grime, 1979) and according to the abiotic conditions (light, moisture, soil $\mathrm{pH}$ and soil nitrogen) were estimated using Ellenberg indicator scales (Ellenberg et al., 1992). For data statistical analysis the ANOVA test was used to estimate the significant variations between gradation classes. A confidence interval of $95 \%$ was used to define the statistical significance (Arhipova \& Bālina, 1999).

\section{Results and Discussion}

Species richness. In the study sites where management activities were carried out regularly, 83 vascular plant and bryophyte species were found, in irregularly managed study sites -86 species, but in 


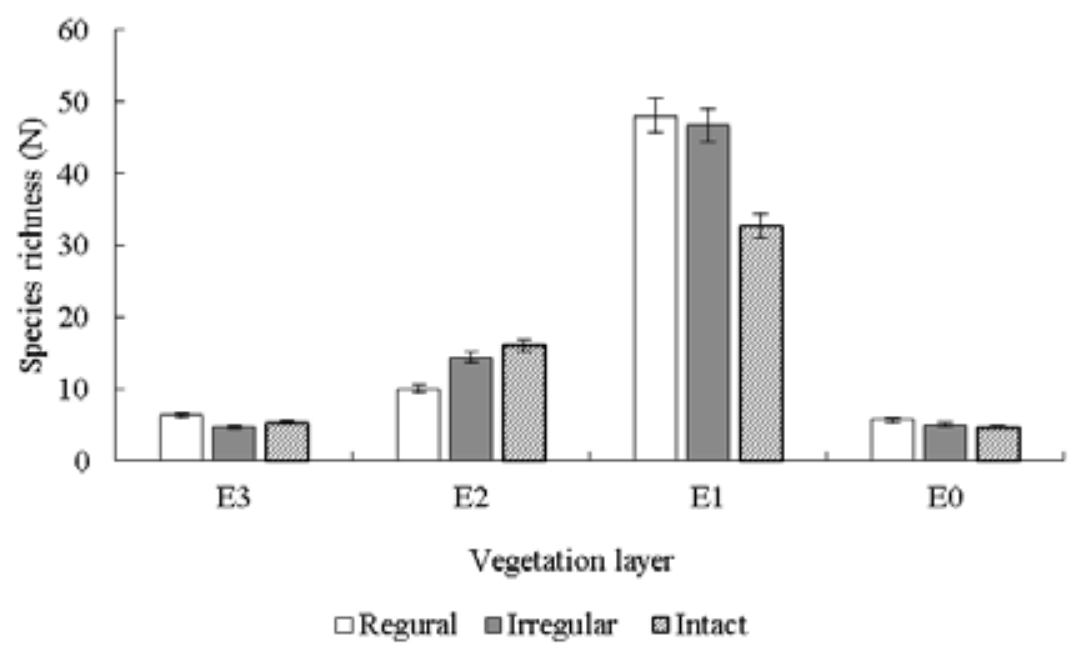

Figure 2. The comparison of species richness by vegation layers in sites with different management. Mean values $\pm \mathrm{SE}$ are shown.

the intact study sites -72 species. Statistical analysis shows that species richness has not been affected by the management activities. This study shows the tendency that species richness in all vegetation layers, except the shrub layer, increases when the management of understory has been done (Fig. 2). This explains the fact that management activities promote the species diversity in herb and moss layers. But when the number of shrub species increases, the species richness in the herb layer decreases.

Species occurrence. In Mežaparks the most common vascular plant species are Pinus sylvestris, Acer platanoides L., Sorbus aucuparia L., Cotoneaster lucidus Schltdl., Fragaria vesca L., Veronica chamaedrys L., Luzula pilosa (L.) Willd., Vaccinium vitis-idaea L., Lerchenfeldia flexuosa (L.) Schur, Polygonatum odoratum (Mill.) Druce and bryophytes - Pleurozium schreberi (Brid.) Mitt. and Hylocomium splendens (Hedw.) Schimp. These species partly correspond to the vegetation characteristic of Myrtillosa forest type (Bušs, 1981; Liepa et al., 2014). In the studied sites where undergrowth management activities have been done regularly, the development of synantrophication and occurrence of invasive vascular plant species was observed, for instance, vascular plants - Sambucus nigra L., Sambucus racemosa L., Symphoricarpos albus L., Amelanchier spicata (Lam.) K. Koch., Impatiens parviflora DC., grasses - Dactylis glomerata L., Agrostis tenuis Sibth., also weeds and meadow species - Stellaria media (L.) Vill., Galium verum L., Knautia arvensis (L.) Coult. Also the species that correspond to forest types on rich soils were also found in these sites - Mycelis muralis (L.) Dum., Geum rivale L., Geum urbanum L., Glechoma hederacea (L.) (Liepa et al., 2014; Straupe, Indriksons,
\& Kazāka, 2014). Also the indicator species of trampling were found (for instance, Plantago major L.), too. It has been observed that after the management activities changes occur in the vegetation succession and soil conditions, increasing fertility, light and moisture availability (Laiviņš \& Laiviņa, 1991). Due to the increase in the level of synantropisation in these habitats, the regeneration probability of Pinus sylvestris L. could decrease. In the study sites where irregular management of understory was found, the appearance of graminification was observed, for instance, the higher occurrence of Dactylis glomerata L., Agrostis tenuis Sibth. as well as a significant increase of typical forest species Lerchenfeldia flexuosa (L.) Schur (Laiviňš, 1998). This successional process could affect the natural regeneration of coniferous species. The dominance of broad-leaved species in the shrub layer (Quercus robur L., Tilia cordata Mill.) could replace the currently existing stands which are dominated by Scots pine (Straupe et al., 2012). In the intact study sites the most common species characterizes the stability in composition of vegetation system and slower succession process.

Projective coverage. The average projective coverage in the studied sites with regular forest management activities differs from $41 \%$ in the tree layer to $1 \%$ in the shrub layer, including $6 \%$ in the moss layer and $25 \%$ in the herb layer (Fig. 3). In the studied sites where irregular forest management activities have been practiced - 36\% (tree layer), $6 \%$ (shrub layer), $14 \%$ (herb layer) and $6 \%$ in moss layer, but in the intact studied sites $-36 \%$ (tree layer), $16 \%$ (shrub layer), 5\% (herb layer) and 6\% (moss layer). When the management activity increases, the projective coverage of shrub layer decreases from $16 \%$ to $1 \%$, but the herb layer increases from $5 \%$ to 


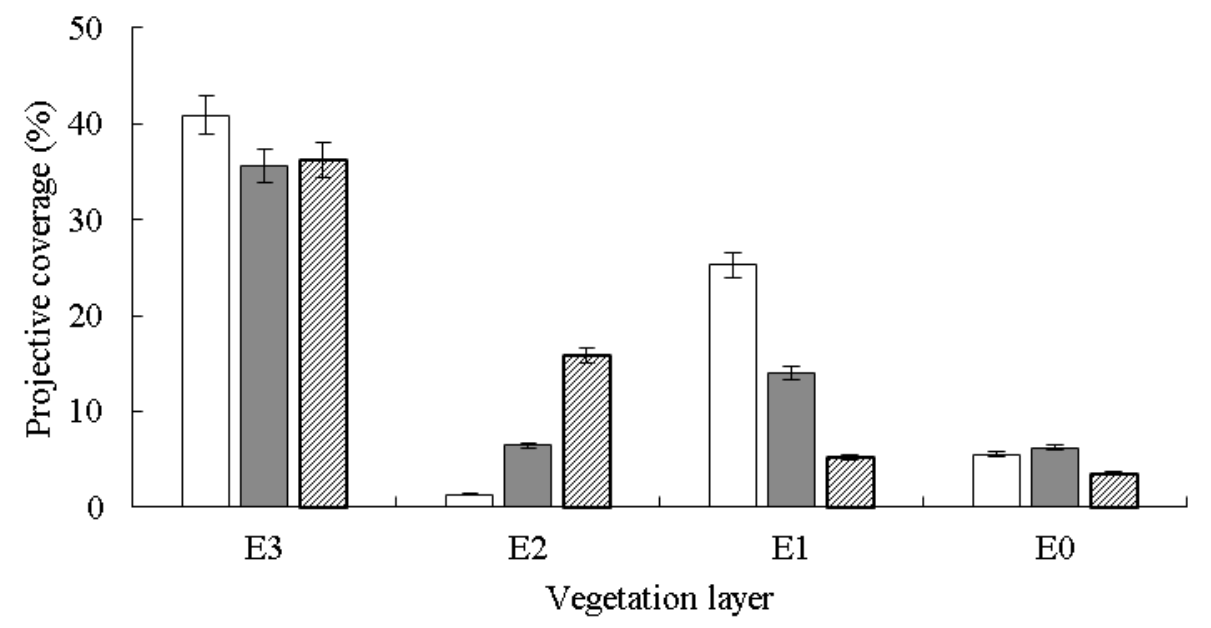

$\square$ Regular $\square$ Irregular $\quad$ Intact

Figure 3. The comparison of projective coverage by vegation layers in sites with different management.

Mean values $\pm \mathrm{SE}$ are shown.

$25 \%$. The total vegetation projective coverage differs significantly when different forest management activity is practiced $(\mathrm{p}<0.05)$.

The results show that the intensity of undergrowth management affects the shrub layer projective cover. After regular management activities, the projective coverage in the shrub layer decreases, but in the herb layer - increases. In the studied sites relatively high proportion in the tree layer consists of broad-leaved species, such as Acer platanoides, Quercus robur and Tilia cordata (Straupe et al., 2012). We also found several species which are indicators for rich soils and broad-leaved forests (Acer platanoides, Quercus robur, Ulmus glabra Huds., Convallaria majalis L. and moss species Rhytidiadelphus triquetrus (Hedw.) Warnst.). In these studied sites, the development of frutification is conducted by the indicator-Amelanchier spicata. In the intact studied sites, the mean cover of the shrub layer is three times higher than coverage in the herb layer. This fact is explained by shady conditions on understory from the shrub layer. In these studied sites, various tree and shrub species are dominant (for instance, Populus tremula L., Acer platanoides and Sorbus aucuparia). The processes of frutification are observed by the dominance of species Cotoneaster lucidus and Cerasus avium (L.) Moench.

The herb layer by strategy types. It is observed that in the studied sites where understory cutting has been practiced regularly, $37 \%$ of all species are competitors (for instance, the most common species are Acer platanoides, Frangula alnus Mill., Quercus robur, Sorbus aucuparia, Ribes spicatum E. Robson and Rubus idaeus L.), but in the studied sites where irregular and intact management has been done 33\% and $40 \%$ respectively. The CSR strategy type species are adaptive to different environmental conditions, for instance, meadow species Galium album Mill., Rumex acetosa L. and Trifolium pratense L. (41\%, $43 \%$ and $48 \%$ respectively). The analysis of strategy types shows that with a decreasing the intensity of management the variablity of the strategy groups (for instance, CSR) increases and the proportion of competitor species decreases.

Ellenberg indicator values. The results show that soil $\mathrm{pH}$ increases when the intensity of understory management activities increases - these areas are characterized by the moderately acidic soils $(\mathrm{pH})$ and are slightly rich in nitrates, but in the studied sites where irregular management activities were practiced - acidic to moderately acidic soils $(\mathrm{pH})$ and poor to moderately alkine. The rich soil indicator species Rhytidiadelphus triquetrus (Hedw.) Warnst. have been surveyed (Liepa et al., 2014).

\section{Conclusions}

1. With the increase in intensity of understory management in Mežaparks, the species richness of herbs and mosses increases by $42 \%$, but the occurrence of shrub species decreases by $45 \%$.

2. The proportion of rare species increases in the stands where regular understory management is practiced and it decreases in sites with an absence of understory management, where the proportion of widespread species increases. This indicates the disruption of relative ecosystem's stability due to management which is considered to be anthropogenic disturbance, after the succession process of vegetation activates and the arrival of new species is observed especially in the herb layer. 
3. In all studied sites, the development of synantrophication was found, especially where frutification was observed by the following species - Sambucus nigra L., Sambucus racemosa L., Symphoricarpos albus L., Amelanchier spicata (Lam.) K. Koch. In the studied sites where understory management was practiced also graminification and presence of ruderal process were also found (grasses - Dactylis glomerata L. and Agrostis tenuis Sibth., weeds - Stellaria media (L.) Vill. and Impatiens parviflora DC.).

4. In all studied sites the regeneration of most common species Pinus sylvestris L. is disturbed as the herb layer consists of excessive projective coverage where understory management was practiced. By contrast, the stands where management is not carried out, a large projective cover consists of a shrub layer, which dominates and creates shady conditions.

5. To continue the further management in these stands, it is essential to provide the presence of characteristic species. We suggest to continue the management activities in the understory, for instance, remove the schrub layer and allow the regrowth of the potential tree layer species.

\section{References}

1. Alvey, A.A. (2006). Promoting and preserving biodiversity in the urban forest. Urban Forestry and Urban Greening, 5(4), 195 - 201. DOI: 10.1016/j.ufug.2006.09.003.

2. Arhipova, I., \& Bāliņa, S. (1999). Statistika ar Microsoft Excel ikvienam (Statistics with Microsoft Excel for everyone). Rīga: Datorzinību Centrs. (in Latvian).

3. Bell, S. (2008). Design for Outdoor Recreation. London: Taylor \& Francis.

4. Bušs, K. (1981). Meža ekologija un tipologija (Forest ecology and typology). Rīga: Zinātne. (in Latvian).

5. Chen, W.C., \& Jim, C.Y. (2008). Assessment and Valuation of the Ecosystem Services Provided by Urban Forests. In M.M. Carreiro, Y.C. Song. \& J. Wu (Eds.), Ecology, Planning, and Management of Urban Forests. International Perspectives (pp. 53 - 83). New York: Springer Science+Business Media, LLC.

6. Dwyer, J.F., McPherson, G.E., \& Schroeder, H.W. (1992). Assessing benefits and costs of the urban forest. Journal of Arboriculture, 18 (5), 227 - 234.

7. Drobyshev, I. (2004). Interactions between climate, natural disturbances, and regeneration in boreal and hemi-boreal forests. Lund: Lund University.

8. Emsis, I. (1980). Rīgas pilsētas meži un to apsaimniekošana (Riga’s urban forests and their management). Rìga: LatZTIZPI. (in Latvian).

9. Ellenberg, H., Weber, H.E., Düll, R., Wirth, V., Werner, W., \& Paulißen, D. (1992). Zeigerwerte von Pflanzen in Mitteleuropa. Göttingen: Verlag Erich Goltze KG.

10. Grime, J.P. (2001). Plant strategies, vegetation processes, and ecosystem properties. Chichester: Wiley.

11. Jakovičs, A. (2013). Mežaparks (Mezaparks). Rīga: Jumava. (in Latvian).

12. Konijnendijk, C.C. (2008). The forest and the city: the cultural landscape of urban woodland. Dordrecht: Springer.

13. Konijnendijk, C.C., \& Randrup, T.B. (2004). Urban Forestry. In J. Burley, J. Evans \& J.A Youngquist (Eds.). Encyclopedia of Forest Sciences (1, pp. 471 - 478). Amsterdam: Elsevier Academic Press.

14. Laiviņš, M. (1998). Latvijas boreālo priežu mežu sinantropizācija un eitrofikācija (Eutrophication and synatrophication of boreal pine forests in Latvia). Rīga: Latvijas Universitāte. (in Latvian).

15. Laiviņš, M., \& Laiviņa, S. (1991). Jūrmalas mežu sinantropizācija (Forest synatrophication in Jurmala). Jaunākais mežzinātnē, 33, 67 - 83. (in Latvian).

16. Liepa, I., Miezīte, O., Luguza, S., Šulcs, V., Straupe, I., Indriksons, A., Dreimanis, A., Saveḷjevs, A., Drēska, A., Sarmulis, Z., \& Dubrovskis, D. (2014). Meža tipologija (Forest typology). Jelgava: studentu biedrība Šalkone. (in Latvian).

17. Markovs, M. (1965). Vispārējā geobotānika (General geobotany). Rīga: Liesma. (in Latvian).

18. Mueller-Dombois, D., \& Ellenberg, H. (1974). Aims and methods of vegetation ecology. New York: Wiley.

19. Priedītis, N. (1999). Latvijas mežs: daba un daudzveidība (Latvia's forest: nature and diversity). Rīga: Pasaules dabas fonds. (in Latvian).

20. Straupe, I., Indriksons, A., \& Kazāka, R. (2014). Koki, krūmi un zemsedzes augi Latvijas mežaudzēs (Trees, shrubs and underground plants in Latvia's forests). Jelgava: studentu biedrība Šalkone. (in Latvian).

21. Straupe, I., Jankovska, I., Rusina, S., \& Donis, J. (2012). The Impact of Recreational Pressure on Urban Pine Forest Vegetation in Riga City, Latvia. International Journal of Energy and Environment, 6, 406 414.

22. Trušiņš, J. (1990). Rekreācija - tautsaimniecības nozare? (Recreation - branch of economy). Rīga: Avots. (in Latvian). 
23. Tyrväinen, L., Pauleit, S., Seeland, K., \& de Vries, S. (2005). Benefits and Uses of Urban Forests and Trees. In C. Konijnendijk, K. Nilsson, T. Randrup, J., \& Schipperijn (Eds.). Urban Forests and Trees (81 - 114). Springer: Berlin Heidelberg. DOI: 10.1007/3-540-27684-X_5.

24. Эмсис, И. (1989). Рекреаџионное использование лесов Латвийской ССР (Recreational use of forests in Latvia). Рига: Зинатне. (in Russian). 